\title{
The Importance of CIR Aerial Imagery in Inventory, Monitoring and Predicting Forest Condition
}

\author{
Jelena Kolić ${ }^{1 \Xi}$, Renata Pernar ${ }^{1}$, Ante Seletković ${ }^{1}$, Mario Ančić ${ }^{1}$
}

\author{
${ }^{1}$ University of Zagreb, Faculty of Forestry, Department of Forest Inventory and Management, Svetošimunska \\ 25, HR-10000 Zagreb, Croatia
}

× Corresponding author: e-mail: jkolic@sumfak.hr

Citation:

KOLIĆ J, PERNAR R, SELETKOVIĆ A, ANČIĆ M 2015 The Importance of CIR Aerial Imagery in Inventory, Monitoring and Predicting Forest Condition. South-east Eur for 6 (2): 191-200. DOI: http://dx.doi.org/10.15177/seefor.15-18

\section{Abstract}

Background and Purpose: The main goal of this paper was to highlight the importance of colour infrared (CIR) aerial photographs for efficient inventory, monitoring and predicting the health status of forests in changed site conditions. CIR aerial photographs from two aerial surveys conducted in 1989 and 2008 were used to identify and analyze the damage in lowland pedunculated oak (Quercus robur L.) forests during each period, as well as to obtain a dieback trend in the observed period.

Material and Methods: The research was conducted in lowland pedunculated oak forests of Josip Kozarac management unit. CIR aerial photographs (1989) of the research area were taken with a classical camera, while aerial images in 2008 were taken with a digital camera and then converted from digital to analogue form (contact copy - photograph) in order to perform photointerpretation with a SOKKIA MS27 Carl ZEISS Jena mirror stereoscope, magnified by 8x. The health status of particular trees (crowns) was assessed by means of photointerpretation keys in a stereomodel over a systematic $100 \times 100 \mathrm{~m}$ sample grid on both 1989 and 2008 aerial photographs. The degree of damage of 4 individual trees was assessed at every grid point in the surveying strips covering the surveyed area. Damage indicators were calculated and thematic maps were constructed on the basis of the interpretation of data for all the grid points.

Results: For the research area a damage index (IO) of $68.36 \%$ for oak was determined by photointerpreting individual trees (2008); in other words, this percentage of pedunculate oak trees in the surveyed area was found to be in the damage degree of 2.1 and more. Of $68.36 \%$ trees classified in the damage degree of 2.1 or more, mean damage $\left(\mathrm{SO}_{1}\right)$ amounted to $52.16 \%$ and could be classified in the damage degree of 2.2. In 1989, the mean damage index (IO) for pedunculate oak was $48.00 \%$, and pedunculate oak trees with mean damage degree of 2.1 or more $\left(\mathrm{SO}_{1}\right)$ amounted to $36.03 \%$. The comparison of photointerpretation results from 1989 and 2008 shows that the damage index (IO) for pedunculate oak increased by more than $20 \%$, whereas mean damage (SO) rose by almost $15 \%$. An increase of more than $15 \%$ in mean damage of considerably damaged pedunculate oak trees can also be observed. 
Conclusions: The obtained results provide not only the current forest condition but also indicate the condition in the field and the purposefulness of aerial surveying, since aerial photographs allow an insight into the condition in the field in a short time period. This in turn enables the efficient application of measures to mitigate the consequences of dieback.

Keywords: CIR aerial photographs, photointerpretation, crown damage, monitoring, pedunculate oak (Quercus robur L.), narrow-leaved ash (Fraxinus angustifolia Vahl.)

\section{INTRODUCTION}

A good quality monitoring of forest damage is based on the systematic collection of data on forests in a particular area and at a particular time. In Croatia, monitoring has been effectively performed by observation in the field since 1987, and by interpretation of colour infrared (CIR) aerial photographs since 1988. Pedunculate oak (Quercus robur L.) forests have for a relatively long time been subjected to changes that fundamentally affect their stability, which is directly reflected on their productivity. According to the results of field assessment of forest damage in Croatia (a method prescribed by ICP Forests), considerable damage of pedunculate oak is gradually increasing, making pedunculate oak the most endangered broadleaved species in Croatia [1, 2].

Tree dieback is a complex process that involves a large number of site, stand and biotic factors [3-8]. The negative consequences are mitigated by monitoring the condition of pedunculate oak trees and by assessing crown damage [9].

Research to date [10-14] show that in terms of accuracy the method of forest damage assessment by photointerpreting CIR aerial images is equal to field method of damage assessment; however, it is much more efficient in terms of work efficiency and objectivity.

According to Kalafadžić and Kušan [15, 16], damage inventories employing aerial photography is based on the assumption that there are explicit differences in the way of mapping between healthy and damaged trees. These differences are conditioned by changes in the spectral system of the reflected solar radiation and by a changed crown shape.
In CIR aerial photographs, forest damage is inventoried by assessing the degree of damage of particular trees (crowns) seen in the aerial photographs. The method of mapping particular degrees is established with a carefully established photointerpretation key [12].

In Croatia, pilot aerial surveys using CIR films $[17,18]$ were followed by the application of CIR aerial photographs to inventory damage over larger areas since 1988 [15, 16, 19]. Forest damage inventory was used to investigate both the impact of some biotic and abiotic factors on stand damage [20] and the reliability of damage assessment in CIR aerial photographs [10]. Remote sensing methods allow for simple monitoring of changes in the forest condition and identifying new hot spots of tree dieback or other damage. This is particularly important in today's changed and disturbed ecological conditions as it makes it possible to predict efficient measures for alleviating dieback consequences [21, 22]. Research to date has shown that more attention should be paid to trees damaged by over $25 \%$, because such trees cannot recover any more; in other words, it is assumed that such trees will die before the end of rotation [4].

Initial aerial survey using CIR film were performed in 1989 over lowland forests of pedunculate oak of Josip Kozarac management unit for the purpose of detecting damage degrees. Since this survey showed all the advantages of photointerpreting CIR aerial photographs for forest damage assessment, the same area was again surveyed 19 years later to monitor the forest condition.

The main goal of this paper was to highlight the importance of CIR aerial photographs for efficient inventory, monitoring and predicting the health status of forests in changed site 
conditions. For that purpose, CIR aerial photographs from two aerial surveys conducted in 1989 and 2008 were used to identify and analyze the damage in lowland pedunculated oak (Quercus robur L.) forests during each period, as well as to obtain a dieback trend in the observed period.

\section{MATERIAL AND METHODS}

As already mentioned, the objects of this research were lowland pedunculated oak forests of Josip Kozarac management unit (MU) (Figure 1).

Josip Kozarac MU has an area about $5500 \mathrm{ha}$, and it is fairly representative of the lowland forests with pedunculate oak and narrow-leaved ash as the main tree species. This area is located about $5 \mathrm{~km}$ south of the Zagreb-Belgrade motorway, near the villages of Kraljevna Velika and Lipovljani, and about
$15 \mathrm{~km}$ south east of Kutina. The hydrological conditions of these forest ecosystems depend on the River Sava, which is about $5 \mathrm{~km}$ south of the facility and its left bank tributaries. The relief is typically lowland, gently rolling, with marked microelevations and micro-depressions, and with the height above sea level being 91$105 \mathrm{~m}$. The age of the forest stands is $105-150$ years.

The area of Josip Kozarac MU was firstly surveyed with CIR film (Kodak Aerochrome 2443) in 1989 using a Zeiss Jena LMK 305/23 camera $(f=305.18 \mathrm{~mm})$, providing analogue CIR aerial photographs in the format $23 \times 23 \mathrm{~cm}$ and with spatial resolution of $50 \mathrm{~cm}$. The average scale of was 1:6100. Ninety compartments were partially or fully captured in a total of 41 aerial photographs with forward overlaps of $60 \%$ and side overlaps of $20-30 \%$ collected in 5 strips. The second aerial survey of the same area was conducted in 2008 with a Microsoft UltraCamX digital large-format aerial camera

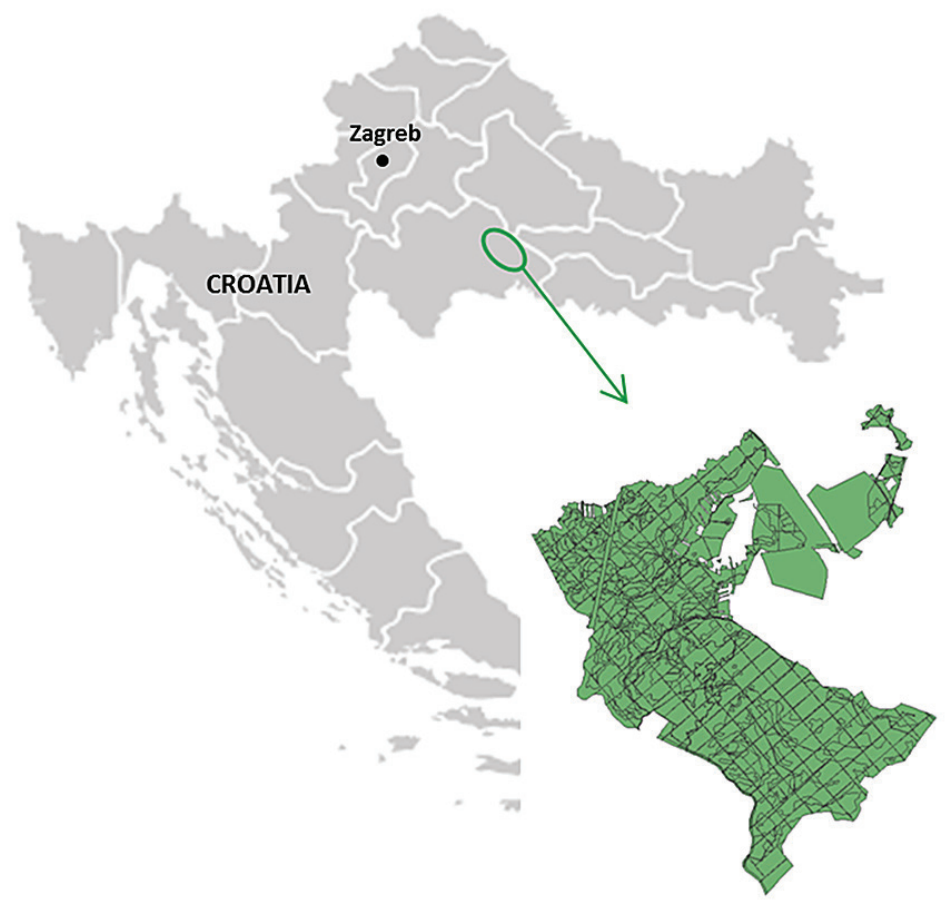

FIGURE 1. The location of the study area - Josip Kozarac management unit 
$(f=100.5 \mathrm{~mm})$. A digital camera was used for the first time for inventory forest damage in Croatian forestry, providing digital CIR aerial images of high spatial resolution (ground sampling distance - GSD). In total, 122 CIR digital aerial images of $10 \mathrm{~cm}$ GSD with forward overlaps of $60 \%$ and side overlaps of $36 \%$ were taken in 12 strips (Figure 2).

According to Figure 2, strips 8527,8528 and 8531 (aerial survey of 2008) fully coincide with strips 537, 538 and 539 (aerial survey of 1989). Since the aerial survey of strips from 2008 covered the entire area of the management unit, the two remaining strips (535 and 536) from the earlier surveying operation are also comparable with the results of photointerpretation.

For the needs of this research, the images from 2008 were converted from digital to analogue form (contact copy - photograph) in order to perform photointerpretation with a SOKKIA MS27 Carl ZEISS Jena mirror stereoscope, magnified by $8 \mathrm{x}$. The photographs from 1989 were also photointerpreted by means of a mirror stereoscope, but on the table for illumination since the recordings were the original films.

Firstly a radial triangulation of aerial photographs was conducted. Prior to photointerpretation, a quality photointerpretation key needs to be established. The photointerpretation keys of the main tree species of Josip Kozarac management unit, pedunculate oak (Quercus robur L.) and narrow-leaved ash (Fraxinus angustifolia Vahl), have already been established within previous studies $[10,22]$ and were used for the purpose of this research. It is important to emphasize that the field data for photointerpretation keys

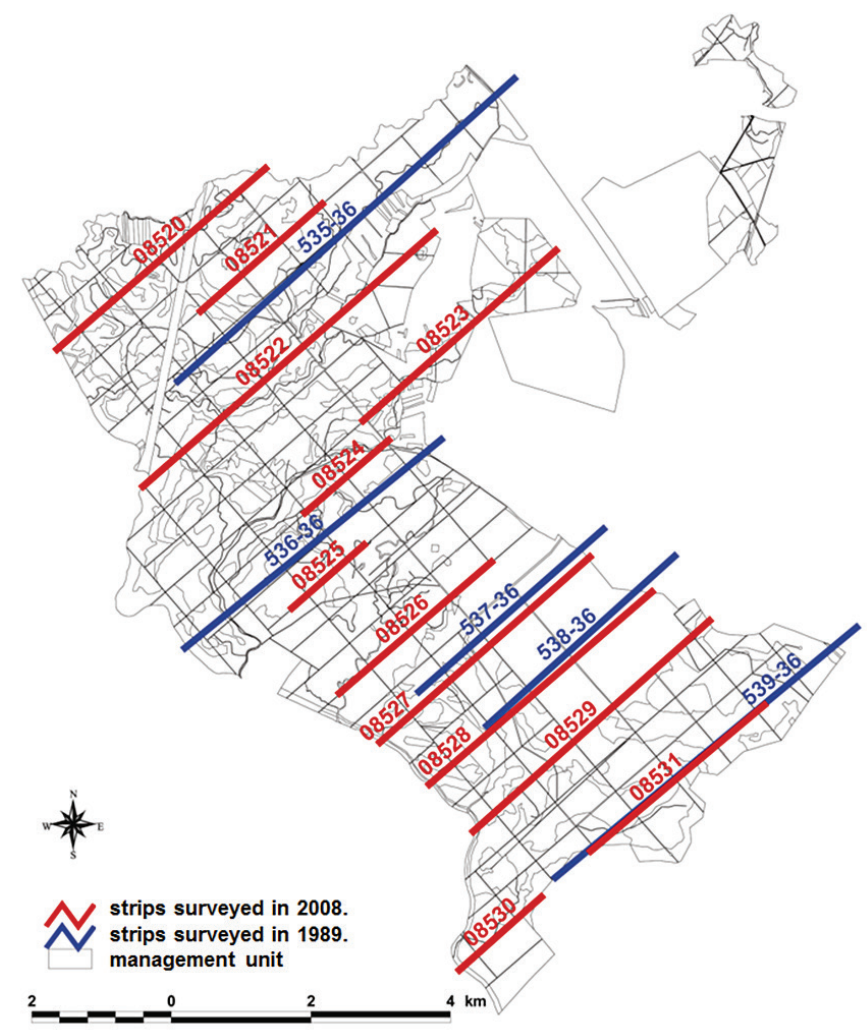

FIGURE 2. Strips surveyed in 1989 and 2008 in Josip Kozarac management unit 
were collected in the same time (vegetation period of 1989 and 2008) as aerial surveys. The trees for which it was assumed that they could easily be detected in aerial photographs were sampled. An attempt was made to achieve it in a sample of a sufficient number of trees in every damage degree. To each selected tree in the field an adequate damage class was assigned. In order to be found in aerial photographs, the position of each tree in the field was outlined in relation to recognizable environmental topographic details. The positions of the trees sampled during 2008 were recorded using Global Positioning System receiver. In addition, especially characteristic trees or group of trees were photographed and described. In this way, most of the sampled trees were identified in the aerial photographs. Finally, the photointerpretation keys were defined on the basis of an idea of how a particular tree species or damage degree are reflected on CIR aerial photographs.

Using previously established photointerpretation keys, the health condition of individual trees (crowns) was assessed in the stereomodel in a systematic $100 \times 100 \mathrm{~m}$ sample grid on both 1989 and 2008 aerial photographs. At each grid point, damage degree was assessed to four individual trees (crowns) closest to the grid point in the upper left and right, and bottom left and right corner. In this way, the damage degree of 4 individual trees (crowns) was assessed on every grid point according to the scale shown in Table 1.

TABLE 1. Damage degree scale

\begin{tabular}{cc}
\hline $\begin{array}{c}\text { Damage degree } \\
(\%)\end{array}$ & $\begin{array}{c}\text { Damage percentage } \\
(\%)\end{array}$ \\
\hline 0 & $0-10$ \\
1 & $11-25$ \\
2.1 & $26-40$ \\
2.2 & $41-60$ \\
3.1 & $61-80$ \\
3.2 & $81-100$ \\
4 & Snags \\
\hline
\end{tabular}

The data for all the grid points were interpreted and damage indicators were calculated according to the following equations [16]:

- Damage (O):

$$
O=\frac{\sum f_{(1-4)}}{\sum f_{(0-4)}} \cdot 100
$$

- Mean damage (SO):

$$
S O=\frac{\sum f_{\mathrm{i}} \cdot x_{\mathrm{i}}}{\sum f_{\mathrm{i}}}
$$

- Damage index (IO):

$$
I O=\frac{\sum f_{(2-4)}}{\sum f_{(0-4)}} \cdot 100
$$

- Mean damage of significantly damaged trees $\left(\mathrm{SO}_{1}\right)$ :

$$
S O_{1}=\frac{\sum f x_{(2-4)}}{\sum f_{(2-4)}}
$$

where:

- $f_{i}$ - number of trees in i - damage stage,

- $x_{i}$ - $i$ - stage interval center in the damage stage scale for single trees $(0=5 \% ; 1=17.5 \%$; $2.1=32.5 \%$; $2.2=50 \% ; \quad 3.1=70 \% ; \quad 3.2=90 \%$; $4=100 \%)$.

A more detailed description of damage indicators can be found in Kalafadžić and Kušan [16] and Pernar et al. [14].

In accordance with the acquired results, thematic maps were constructed using ArcGIS 9.2 software in a scale of 1:5000 with spatial distribution of mean damage (SO) and damage index (IO) for the main tree species, and overall for the management units (compartments/ subcompartments) in individual recording strips.

\section{RESULTS AND DISCUSSION}

Damage indicators for the main tree species (pedunculate oak and narrow-leaved ash) and overall for the management unit were calculated on the basis of the results of CIR aerial photograph interpretation from two surveying periods (Table 2 ). 
A comparison of significant oak damage (IO) from two surveying periods shows that oak damage was higher in 2008, i.e. it rose by about 20\% (Table 2, Figure 3). Mean damage of significantly damaged trees also increased (36.03\% in $2008,52.16 \%$ in 2008). This is also confirmed by the results of field assessment of forest damage in Croatia (a method prescribed by ICP Forests), stating that significant damage of pedunculate oak has been gradually increasing since 2002 , thus making pedunculate oak the most endangered broadleaves species in Croatia [1, 2].

As for ash (Table 2, Figure 4), mean damage increased only slightly (in 1989, SO $=28.87 \%$; in 2008 , SO $=30.59 \%$ ). Significant damage was even lower than in the earlier surveying period (in 1989, IO $=58.40 \%$; in 2008, IO $=56.74 \%$ ). This coincides with ash weevil outbreaks recorded in the area in 1989.

This is also illustrated by mean damage of significantly damaged trees $\left(\mathrm{SO}_{1}\right)$, which in the case of ash is on a slight rise, unlike mean damage of significantly damaged pedunculate oaks, which rose by about $16 \%$. Consequently, a slightly higher damage percentage in ash is attributed to pest attacks [23], whereas in the case of oak, damage shows continuous rise: unlike ash, the crown structure in oak is also disturbed. If the amount of assimilation organs is decreased, the intensity of radiation reflected from these organs also decreases, forcing other parts of the tree - shoots, branches and stem,

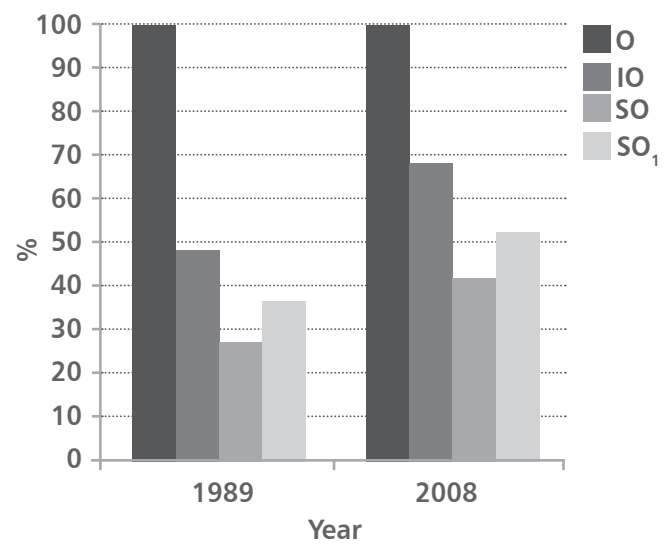

FIGURE 3. Comparison of pedunculate oak damage indicators for two surveying periods

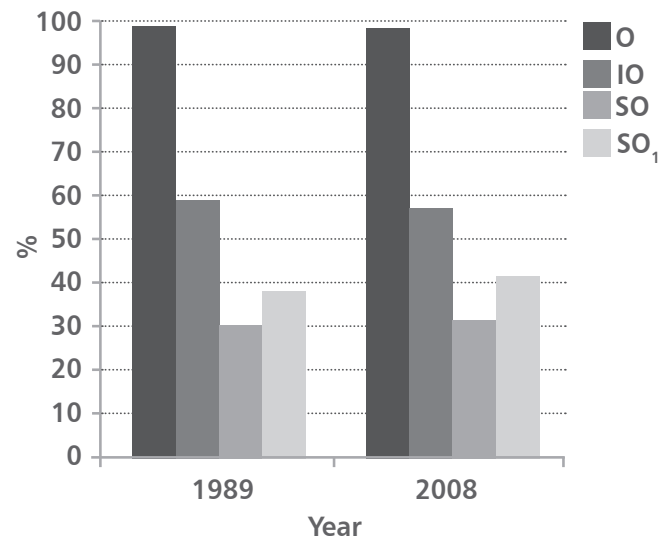

FIGURE 4. Comparison of narrow-leaved ash damage indicators for two surveying periods

TABLE 2. Damage indicators for Josip Kozarac management unit (aerial survey in 1989 and 2008)

\begin{tabular}{ccccccc}
\hline & \multicolumn{3}{c}{ Tree species } \\
Damage indicators & \multicolumn{3}{c}{ Pedunculate oak } & \multicolumn{3}{c}{ Year } \\
\cline { 2 - 7 } & 1989 & 2008 & 1989 & 2008 & 1989 & 2008 \\
\cline { 2 - 7 } O & 99.83 & 99.26 & 98.37 & 97.92 & 98.89 & 98.77 \\
IO & 48.00 & 68.36 & 58.40 & 56.74 & 50.70 & 64.12 \\
SO & 26.37 & 41.10 & 28.87 & 30.59 & 27.02 & 37.26 \\
SO & 36.03 & 52.16 & 37.50 & 41.02 & 36.64 & 48.56 \\
\hline
\end{tabular}

$\mathrm{O}$ - damage; IO - damage index; SO - mean damage; $\mathrm{SO}_{1}$ - mean damage of significantly damaged trees 
to participate in the reflection process [24]. This results in decreased intensity of red colour, which in turn affects the assessment of crown damage.

In terms of mean damage (total) in 2008 SO $=37.26 \%$, it can be seen that it is higher in relation to 1989 - SO $=27.02 \%$ (Table 2, Figure 5). Significant damage also increased. In 1989, $50.70 \%$ of the trees were damaged above $25 \%$, while in $2008,64.12 \%$ of the trees were damaged above $25 \%$.

The obtained results of damage detection show distinct oak damage in the surveyed area. Research to date indicates that more attention should be paid to significantly damaged trees, since such trees are hard to recover, or in other words, it is assumed that they will die before the end of rotation. An increasing proportion of sanitary fellings in the annual cuts forces us to pay particular attention to the health status of forests and the amount of unplanned felling: therefore, we also analyzed the delineation selection of the compartments/ subcompartments in which photointerpretation of CIR aerial images showed that oak damage exceeded $60 \%$, or in which more than $50 \%$ of the trees were significantly damaged (IO),

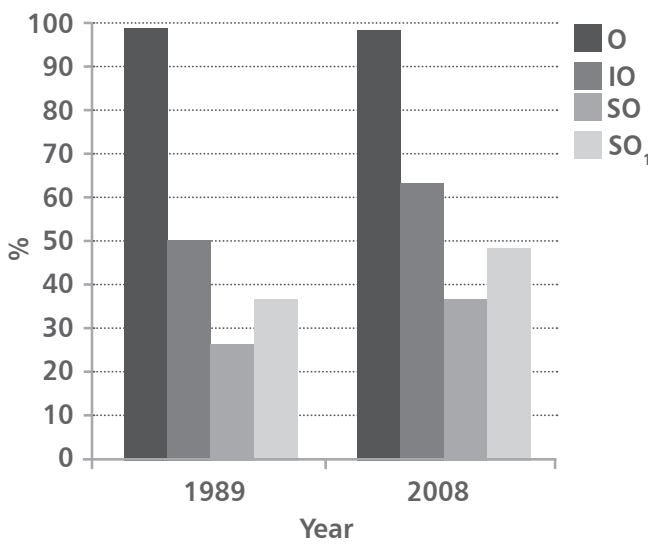

FIGURE 5. Comparison of damage indicators overall for all the interpreted species from two surveying periods

according to the quantity of sanitary fellings. Infrared digital orthophoto (1:5000) was used to inventory (map) more severely damaged trees and snags, whose marking provided spatial distribution in the surveyed area (Figure 6). According to the results, the highest number of trees marked for sanitary fellings were found precisely in the compartments in which photointerpretation revealed the highest

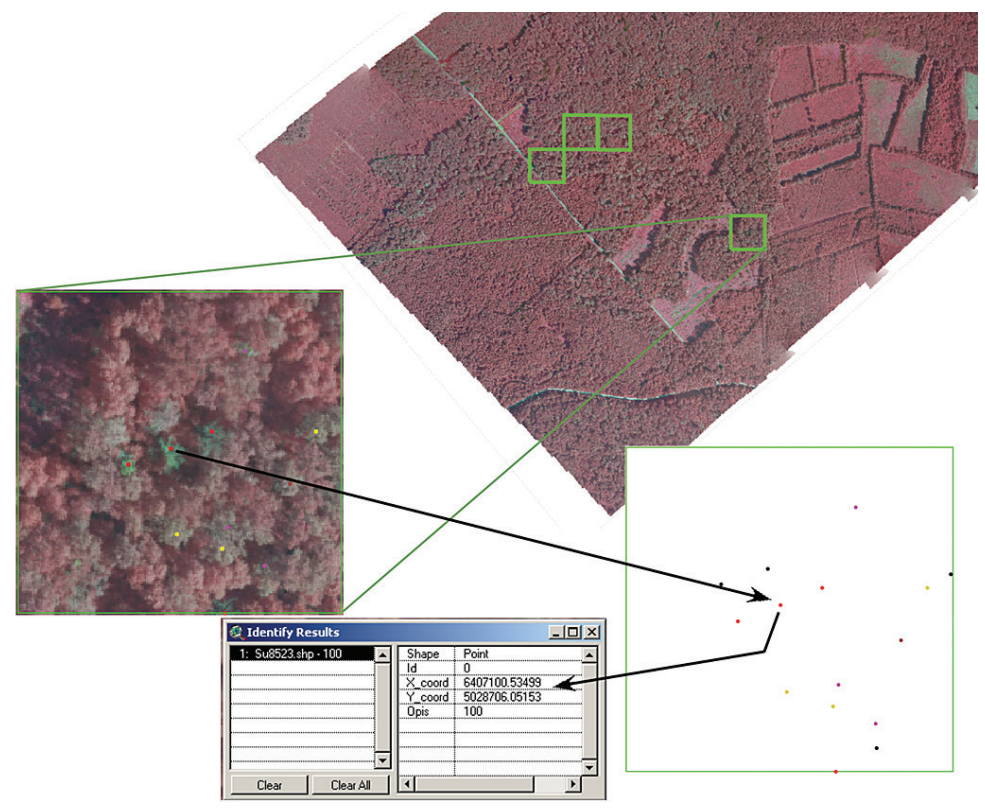

FIGURE 6. Excerpt from a surveying stripe (2008) with mapped trees in 1 ha samples (snags are marked red, and trees in damage degrees 3.1 and 3.2 are marked yellow and purple) 
damage degrees (2b, 3a, 3b) (Figure 7).

Identifying and monitoring the spatial distribution of damaged trees and snags is one of the priorities of sustainable management [19]. Therefore, timely location of stands of poorer health is necessary so that appropriate measures can be applied to maintain their vitality and productivity at an optimal level. This is enabled by interpretation of CIR aerial photographs. The achieved results provide not only the current forest condition, but also indicate the condition in the field and the purposefulness of aerial surveying. Aerial photographs allow an insight into the field condition in a short time period and enable efficient prediction of measures to alleviate dieback consequences.

\section{CONCLUSIONS}

The results obtained by photointerpreting CIR images from two periods for the area of Josip Kozarac management unit relate to identifying and analyzing damage in pedunculate forests, as well as obtaining data on the spatial distribution of damage. They serve as a basis for the study of characteristics that affect the health condition of pedunculate oak forests.

A comparison of the results of photointerpretation for the period of the past 19 years shows that, in terms of all the interpreted species (overall), mean damage rose by about $10 \%$ in relation to 1989 . In contrast, the damage index is higher by about 14\%, i.e., 19 years ago there were $50.70 \%$ trees in the damage degree of 2.1 and more, whereas in 2008, there were $64.12 \%$ trees in this degree. In terms of oak damage, SO $=41.10 \%$ in 2008, and SO = $26.37 \%$ in 1989 . This means that mean damage for pedunculate oak rose by about $15 \%$ over a period of 19 years.

The acquired results provide an insight into the condition of pedunculate oak in the surveyed area and can serve as a basis for future planning of this area in changed site conditions. They can also be used to predict future development and assess the probability and pace of dieback.
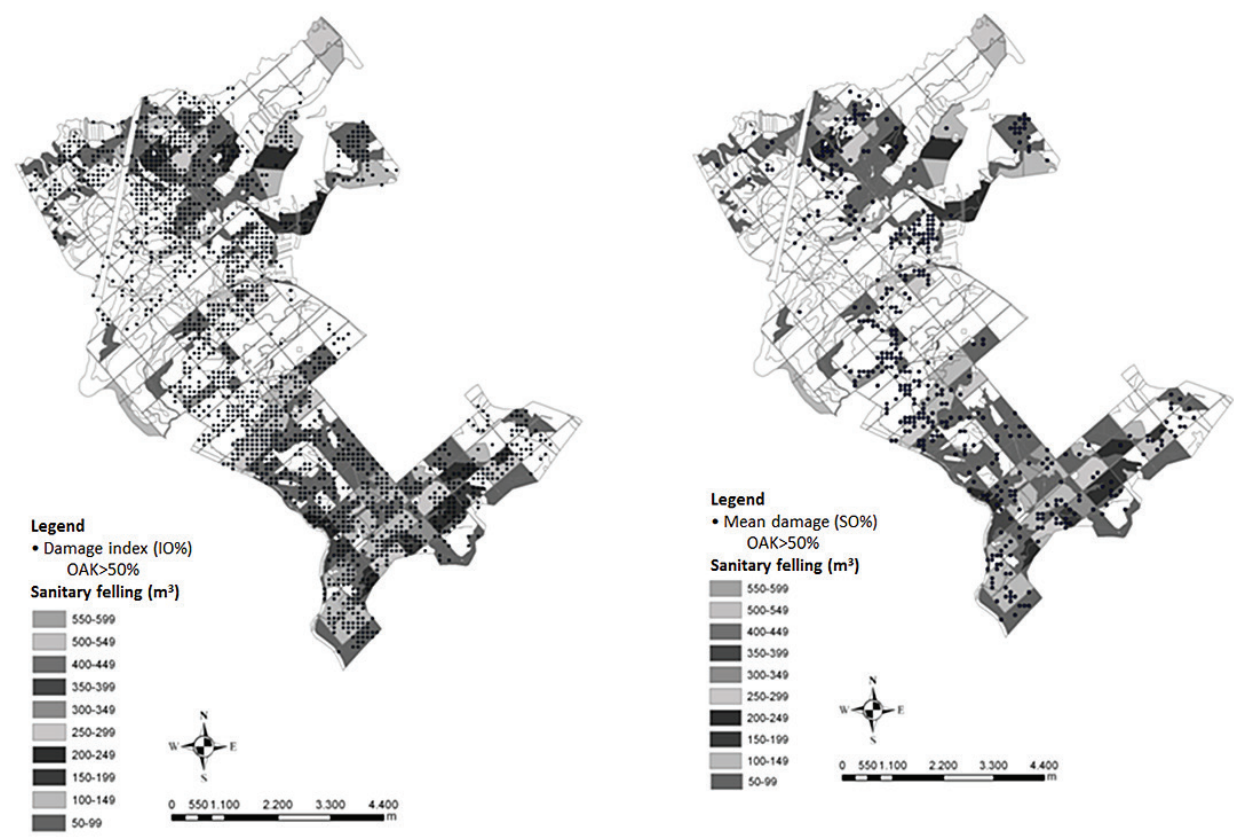

FIGURE 7. Spatial distribution of damaged trees and snags and sanitary fellings 


\section{REFERENCES}

1. SELETKOVIĆ I, РОTOČIĆ N 2004 Crown Condition of Forests in Croatia for the Period 1999-2003 (in Croatian with English summary). Sumar List 128 (3-4): 137-148

2. РОTOČIĆ N, SELETKOVIĆ । 2011 Defoliation of Forest Trees in Croatia in the period 2006 - 2009 (in Croatian with English summary). Sumar List, 135 (13): 149-158

3. HARAPIN $M$, ANDROIĆ $M 1996$ Drying and protection forests of penduculate oak. In: Klepac D (ed) Pedunculate oak (Quercus robur L.) in Croatia. Croatian Academy of Science and Arts Vinkovci Centre for Scientific Work and Croatian Forests Ltd., pp 227-256

4. PRPIĆ B 1996 The decline of pedunculated oak forest. In: Klepac D (ed) Pedunculate oak (Quercus robur L.) in Croatia. Croatian Academy of Science and Arts - Vinkovci Centre for Scientific Work and Croatian Forests Ltd., pp 273-298

5. WARGO PM 1996 Consequences of environmental stress on oak: predisposition to pathogens. Ann For Sci 53 (2-3): 359-368. DOl: http://dx.doi. org/10.1051/forest:19960218

6. DONAUBAUER E 1998 Die Bedeutung von Krankheitserregern beim gegenwärtigen Eichensterben in Europa - eine Literaturübersicht (in German with English summary). Eur J For Path 28 (2): 91-98. DOI: http://dx.doi. org/10.1111/j.1439-0329.1998.tb01170.x

7. FÜHRER E 1998 Oak decline in Central Europe: A synopsis of hypotheses. In: McManus ML, Liebhold AM (eds) Proc. Population Dynamics, Impacts, and Integrated Management of Forest Defoliating Insects. USDA Forest Service General Technical Report NE-247. USDA, Washington (DC), USA, pp 7-24

8. THOMAS FM, BLANK R, HARTMANN G 2002 Abiotic and biotic factors and their interactions as causes of oak decline in Central Europe. Forest Pathol 32 (4-5): 277-307. DOI: http://dx.doi. org/10.1046/j.1439-0329.2002.00291.x

9. DUBRAVAC T, DEKANIĆ S, ROTH V 2011 Damage Dynamics and Structure of the Pedunculate Oak Tree Crowns in Stands in Microelevations and Microdepressions - Results from the Monitoring on Permanent Experimental Plots (in Croatian with English summary). Sumar List 128 (3-4): 74-89
10. PERNAR R 1994 Method and Reliability of Assessing Pedunculate Oak (Quercus robur L.) Damage on Colour Infrared (CIR) Aerial Photographs (in Croatian with English summary). Glasnik za šumske pokuse 31:1-34

11. PERNAR R 1997 Application of results of aerial photograph interpretation and geographical information system for planning in forestry. Glasnik za šumske pokuse 34: 141-149

12. PERNAR R, ANČIĆ M, SELETKOVIĆ A 2007 Application of Colour Infrared Aerial Photographs for the Assessment of Forest Damage in the Gospić Forest Administration (in Croatian with English summary). Sumar List 131 (11-12): 507-521

13. PERNAR R, BAJIĆ $M$, ANČIĆ $M$, SELETKOVIĆ A, IDŽOJTIĆ M 2007 Detection of mistletoe in digital colour infrared images of infested fir trees. Period Biol 109 (1): 67-75

14. PERNAR R, SELETKOVIĆ A, ANČIĆ M, VEDRIŠ M, TESLAK K 2008 Assessing the health status of beech-fir forests using remote sensing methods. Period Biol 110 (2): 157-161

15. KALAFADŽIĆ Z, KUŠAN V 1990 Assesment of forest decline on big areas using colour infrared (CIR) aerial photographs (in Croatian with English summary). Glasnik za šumske pokuse 26: 447- 459

16. KALAFADŽIĆ Z, KUŠAN V 1990 Defining the degree of damage in forest trees and stands (in Croatian with English summary). Sumar List 114 (11-12): 517-526

17. TOMAŠEGOVIĆ Z 1982 The possibility of applying false color aerial photographs in the study of the environment in order spatial planning (in Croatian with English summary). Bilten Savjeta za daljinska istraživanja i fotointerpretaciju, JAZU 3: 7-12

18. KALAFADŽIĆ Z 1987 Application of CIR aerial photographs in forestry (in Croatian with English summary). Sumar List 111 (1-2): 61-66.

19. PERNAR R, SELETKOVIĆ A, ANČIĆ M, SUČIĆ J 2011 Features of Spatial Snag Distribution in a Beech-Fir Forest. Croat J For Eng 32 (1): 313-327

20. KALAFADŽIĆ Z, KUŠAN V, HORVATIĆ Z, PERNAR R 1993 Forest Decline Inventories in Republic of Croatia Using Colour Infrared (CIR) Aerial Photographic (in Croatian with English summary). Glasnik za šumske pokuse, special issue 4: 163172 
21. PERNAR $R$, SELETKOVIĆ A, ANČIĆ M 2009 Monitoring the condition of pedunculate oak forests with remote sensing methods. In: Matić S, Anić I (eds) Forests of Pedunculate oak in Changed site and management conditions, Zagreb, Croatia, 24-25 September 2008. Croatian Academy of Science and Arts, Zagreb, Croatia, pp 103-115

22. PERNAR R, SELETKOVIĆ A, ANČIĆ M 2009 Establishing forest damage inventory and dryer area MU Josip Kozarac-Forest Office Lipovljani. Study
23. FLISZAR I 1990 Inventory of damage to trees and stands of European ash (Fraxinus angustifolia Vahl.) due to the intensity of attacks ash weevil (Stereonychus fraxini Degeer) interpretation of CIR aerial photographs (in Croatian). Thesis, University of Zagreb, Faculty of Forestry, Zagreb, Croatia, $54 \mathrm{p}$

24. KADRO A 1984 Investigation of Spectral Signatures of differently damages trees and forest stands using multispectral data. Proceedings of IGARSS'84 Symposium, Strasburg, France. ESA Scientific and Tech. Pub. Branch, ESA SP-215 (1): 217-221

(C) 2015 by the Croatian Forest Research Institute. This is an Open Access paper distributed under the terms of the Creative Commons Attribution License (http://creativecommons.org/licenses/by/4.0). 